\title{
VPAC2 receptor agonist BAY 55-9837 increases SMN protein levels and moderates disease phenotype in severe spinal muscular atrophy mouse models
}

\author{
Jeremiah Hadwen ${ }^{1,2+}$, Duncan MacKenzie ${ }^{2 \dagger}$, Fahad Shamim², Kevin Mongeon ${ }^{1,2}$, Martin Holcik ${ }^{1,2}$, \\ Alex MacKenzie ${ }^{1,2^{*}}$ and Faraz Farooq ${ }^{2^{*}}$
}

\begin{abstract}
Background: Spinal Muscular Atrophy (SMA) is one of the most common inherited causes of infant death and is caused by the loss of functional survival motor neuron (SMN) protein due to mutations or deletion in the SMN1 gene. One of the treatment strategies for SMA is to induce the expression of the protein from the homologous SMN2 gene, a rescuing paralog for SMA.

Methods and results: Here we demonstrate the promise of pharmacological modulation of SMN2 gene by BAY 55-9837, an agonist of the vasoactive intestinal peptide receptor 2 (VPAC2), a member of G protein coupled receptor family. Treatment with BAY 55-9837 lead to induction of SMN protein levels via activation of MAPK14 or p38 pathway in vitro. Importantly, BAY 55-9837 also ameliorated disease phenotype in severe SMA mouse models.
\end{abstract}

Conclusion: Our findings suggest the VPAC2 pathway is a potential SMA therapeutic target.

Keywords: p38 pathway, SMN, SMA, VPAC2 receptor agonist, Therapeutics

\section{Background}

Spinal muscular atrophy (SMA), is an untreatable recessive neuromuscular disorder; with an incidence of $1: 11000$, it is a leading genetic cause of pediatric death [1]. The loss of lower motor neurons from the ventral horn of spinal cord is the major pathological feature of the disease and results in generalized weakness, progressive muscle loss and respiratory failure [2]. SMA is caused by the pathologic reduction in survival of motor neuron (SMN) protein levels due to deletions and mutations in SMN1 gene [3]. Although the complete loss of SMN protein is embryonically lethal, the presence of the paralogous $S M N 2$, a result of a recent duplication event, which produces a limited full length SMN mRNA $(\sim 10 \%)$ precludes this outcome in humans [4,5]. Thus all SMA patients have 2 or more copies of SMN2 gene

\footnotetext{
* Correspondence: MacKenzie@cheo.on.ca; faraz@arc.cheo.ca

${ }^{\dagger}$ Equal contributors

'University of Ottawa, Ottawa K1H 8M5, Canada

${ }^{2}$ Children's Hospital of Eastern Ontario Research Institute, Apoptosis Research Centre, 401 Smyth Road, Ottawa, Ontario K1H 8L1, Canada
}

which in part compensates for the loss of SMN1 gene. The inverse correlation between the severity of the disease phenotype and copy number of SMN2, both confirms the gene's disease modifying function and has made the induction of SMN2 a common SMA therapeutic goal. In this regard we have showed the post transcriptional stabilization of SMN mRNA through activation of p38 pathway leads increased SMN levels [6]. We have recently reported that the activation of the p38 pathway through celecoxib upregulates SMN protein levels and can ameliorate disease phenotype in SMA mouse model [7]. In this regard, Vasoactive intestinal peptide receptor 2 (VPAC2), a member of G protein coupled receptor family when activated has been reported to activate $\mathrm{p} 38$ pathway in vivo $[8,9]$.

We thus decided to assess the blood brain barrier (BBB) penetrant VPAC2 receptor agonist BAY 55-9837 for its potential SMA therapeutic utility. We show here that BAY 55-9837 conferred an increase in SMN protein levels via p38 activation in human neuronal cells. Importantly, we 
show that treatment with BAY 55-9837 also increases brain and spinal cord SMN protein levels as well as improving disease phenotype and survival in a severe SMA mouse model. Our results provide further evidence that p38 MAPK pathway activators act as potential therapeutic compounds for the treatment of SMA and identify the VPAC pathway as one means of achieving such activation.

\section{Methods}

Animals

All protocols were approved by Animal Care and Veterinary Services (ACVS) and Ethics board of University of Ottawa. All experiments were carried out in accordance with the Canadian Institute of Health Research (CIHR) Guidebook and ACVS legislation. CD-1 mice were obtained from Charles River Laboratory. The original breeding pair of heterozygous SMA $\Delta 7(m S m n+/-$, $h S M N 2+/+, h S M N \Delta 7+/+$; stock\# 005025), Taiwanese mice (Smn1 ${ }^{\text {tm1Hung }} \mathrm{Tg}(\mathrm{SMN} 2) 2 \mathrm{Hung} / \mathrm{J}$; stock\# 005058) and heterozygous Smn knock-out mice $\left(\mathrm{Smn}^{+/-}\right)$on the FVB background were provided by the Jackson Laboratory. The animals were maintained in an air-conditioned ventilated animal facility. Survival, righting time and weight were monitored daily as described by Aviva et al [10].

\section{BAY 55-9837 administration}

BAY 55-9837 was diluted in $\mathrm{PBS} / \mathrm{dH}_{2} \mathrm{O}$ and administered through IP injection using a 30-gauge needle $(0.2$ $\mathrm{mg} / \mathrm{kg}$ dose). Control animals received equal volumes of vehicle alone. SMA $\Delta 7$ and Taiw/Jax SMA mice were genotyped at P0 and BAY 55-9837 treatment was started from P1. Animals were sacrificed within twenty four hours of the final dose.

\section{Reagents}

BAY 55-9837 was purchased from Tocris Bioscience. p38 inhibitor SB239063 was purchased from Sigma. The antibodies used in this study were SMN/Smn (BD Transduction Laboratories), Actin (Abcam), Tubulin (Abcam), Phosphop38 (Cell signalling) and Total p38 (Cell signalling).

\section{Cell culture and drug treatment conditions}

Human neuron-committed teratocarcinoma (NT2), mouse motor neuron derived (MN-1) cells and SMA type I patient fibroblasts were maintained in standard conditions $\left(37^{\circ} \mathrm{C}\right.$ in a $5 \% \quad \mathrm{CO}_{2}$ humidified atmosphere) in Dulbecco's modified Eagle medium (DMEM) supplemented with $10 \%$ fetal calf serum (FCS), 1\% antibiotics (100 units/ $\mathrm{ml}$ penicillin-streptomycin) and $2 \mathrm{mM}$ glutamate.

NT2 or MN-1 cells were seeded in 6 well plates $(5 \times$ $10^{5}$ cells/well) and treated $24 \mathrm{~h}$ later with BAY 55-9837 $(0.25 \mu \mathrm{M})$ for $24 \mathrm{~h}$. For time course experiment, NT2 cells were seeded in 6 well plates $\left(5 \times 10^{5}\right.$ cells/well $)$ and treated 24h later with BAY 55-9837 $(0.25 \mu \mathrm{M})$ for up to 24h. For p38 inhibitor treatment, NT2 were seeded in 6 well plates $\left(5 \times 10^{5}\right.$ cells/well $)$ and pre-treated with $\mathrm{p} 38$ inhibitor SB239063 for $2 \mathrm{~h}$ followed by BAY 55-9837 treatment $(0.25 \mu \mathrm{M})$ for $24 \mathrm{~h}$.

\section{Western blot analysis}

Cells were washed 2 times with $1 \mathrm{ml}$ PBS (1X) and lysed in $150 \mu \mathrm{l}$ RIPA buffer containing $10 \mathrm{mg} / \mathrm{ml}$ each of aprotinin, PMSF and leupeptin (all from Sigma), $5 \mathrm{mM}$ $\beta$-Glycerolphosphate, $50 \mathrm{mM} \mathrm{NaF}$ and $0.2 \mu \mathrm{M}$ sodium orthovanadate for $30 \mathrm{~min}$ at $4^{\circ} \mathrm{C}$, followed by centrifugation at $13000 \times \mathrm{g}$ for $30 \mathrm{~min}$; supernatants were then collected and kept frozen at $-20^{\circ} \mathrm{C}$. Tissue samples were homogenized in $0.5 \mathrm{ml} \mathrm{RIPA}(10 \mathrm{mg} / \mathrm{ml}$ each of aprotinin, PMSF and leupeptin) and then sonicated for 15 seconds. Total protein concentrations were determined by Bradford protein assay using a Bio-Rad protein assay kit. For western blot analysis, protein samples were separated by $11 \%$ SDS-PAGE. Proteins were subsequently transferred onto nitrocellulose membrane and incubated in blocking solution (PBS, 5\% non-fat milk, 0.2\% Tween-20) for $1 \mathrm{~h}$ at room temperature followed by overnight incubation with primary antibody at $4{ }^{\circ} \mathrm{C}$ at the dilution prescribed by the manufacturer. Membranes were washed with PBS-T (PBS, and 0.2\% Tween-20) 3 times followed by incubation with secondary antibody (anti-mouse or rabbit, Cell signalling) for $1 \mathrm{~h}$ at room temperature. Antibody complexes were visualized by autoradiography using the ECL Plus and ECL western blotting detection systems (GE Healthcare). Quantification was performed by scanning the autoradiographs and signal intensities were determined by densitometric analysis using the ImageJ program.

\section{Primer sequences}

\section{For genotyping}

Genotyping was performed as previously described by Aviva et al [10] for SMA $\Delta 7$ mice using the following primers

mSmn WT Forward: 5 '-TCTGTGTTCGTGCGTGGTG ACTTT-3'.

Reverse 1877: 5'-CCCACCACCTAAGAAAGCCTCA AT-3'.

Lac Z Forward: 5 '-CCAACTTAATCGCCTTGCAGCA CA-3'.

Reverse: 5' -AAGCGAGTGGCAACATGGAAATCG 3'.

Human SMN2 transgene Forward: 5'-CAAACACCT GGTATGGTCAGTC-3'.

Reverse: 5'-GCACCACTGCACAACAGCCTG-3' .

Product sizes:

mSMN: 372 bp 
Lac Z: 626 bp

SMN2 transgene: $250 \mathrm{bp}$

Genotyping for Taiwanese SMA mice was performed as previously described by Riessland et al [11] using recommended primers.

\section{Statistical methods}

GraphPad Prism software package was used for the Kaplan-Meier survival analysis. The log-rank test was used and survival curves were considered significantly different at $\mathrm{P}<0.05$.

Data in figures (histograms, points on graphs) are mean values with the standard error mean (SEM) shown as error bars. The Student's two-tail $t$ test was used to test for statistical differences between samples and were considered significantly different at $P<0.05$.

\section{Results and discussion}

SMA is a frequently severe neurodegenerative disease which most frequently affects children; many of them do not survive beyond the first few years of life. Although there is no effective therapy for SMA, one translational approach is to induce the paralogous gene SMN2. This results in the production of more SMN protein, which can partially compensate for the loss of SMN1 gene and to moderate the disease phenotype.

BAY 55-9837 treatment upregulates SMN protein in vitro VPAC2 receptor activation has been reported to activate the p38 kinase pathway [8,9] which, in turn, we have shown to stabilize SMN transcript and increase SMN protein level [6]. In order to assess the potential of VPAC-2 receptor activation in the regulation of SMN gene expression; human NT2, mouse MN-1 cells and SMA I patient fibroblasts were treated with VPAC2 receptor agonist BAY 55-9837 $(25 \mu \mathrm{M})$ for $24 \mathrm{~h}$ and subsequently harvested for western blot analysis. SMN protein levels were found to be increased by $\sim 2$ fold in all cell lines upon treatment with BAY 55-9837 (Figure 1a-f). These results were encouraging in that the increase in SMN protein levels was observed in both neuronal cell lines and patient fibroblasts suggesting that the induction was not specific to a given cell line.

\section{BAY 55-9837 conferred increase in SMN protein levels is} mediated by $\mathrm{p} 38$ MAPK activation

The p38 MAPK pathway regulates a number of cellular process including post-transcriptional stabilization of a distinct class of mRNAs that contain AU rich elements (ARE) mapping to their 3' UTRs [12-16]. This class of

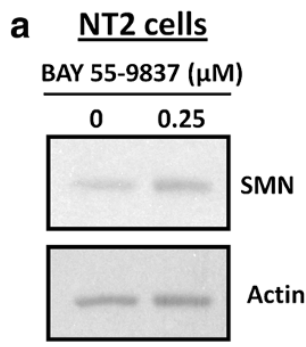

b

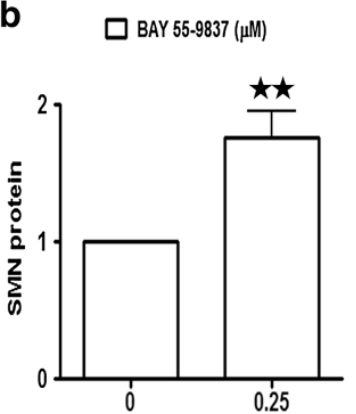

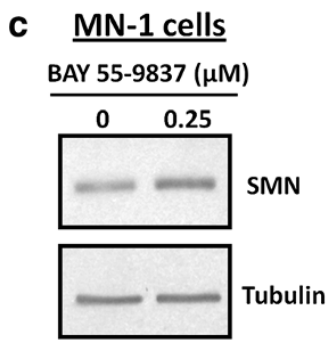

d $\square$ BAY $55.9837(\mu M)$

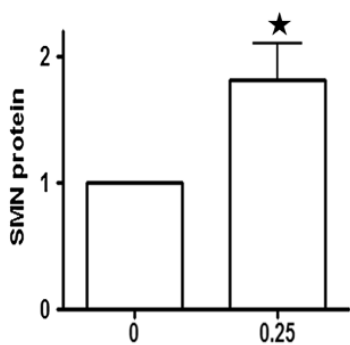

e SMA I patient fibroblast

BAY 55-9837 ( $\mu \mathrm{M})$

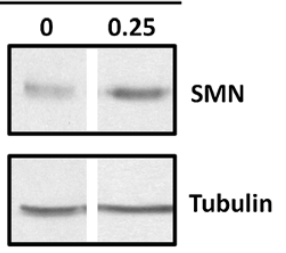

f

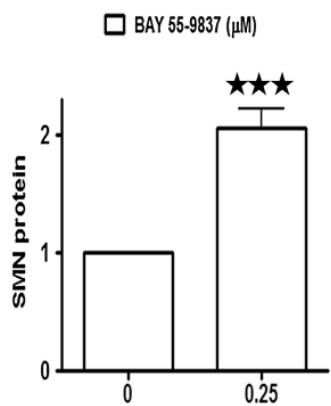

Figure 1 BAY 55-9837 treatment upregulates SMN protein in vitro. NT2, MN-1 and SMA I patient fibroblasts were treated with BAY 55-9837 $(0.25 \mu \mathrm{M})$ and then harvested at 24 hours for western blot analyses. (a) Representative western blots showing the effect of BAY 55-9837 on SMN protein in NT2 cells. (b) Densitometric quantification of SMN protein relative to Actin (the ratio at control treatment was set as 1; mean + SEM (bars) of six independent experiments) are shown for NT2 cells. (c) Representative western blot showing effect of BAY 55-9837 on SMN protein in MN-1 cells. (d) Densitometric quantification of SMN protein relative to Tubulin (the ratio at control treatment was set as 1; mean + SEM (bars) of three independent experiments) are shown for MN-1 cells. (e) Representative western blots showing the effect of BAY 55-9837 on SMN protein in SMA I patient fibroblasts (all lanes were run on the same gel but were non-contiguous). (f) Densitometric quantification of SMN protein relative to Tubulin (the ratio at control treatment was set as 1; mean + SEM (bars) of five independent experiments) are shown for SMA I patient fibroblasts. ${ }^{* P}<0.05 ;{ }^{* * P}<0.01 ;{ }^{* * P}<0.001$, t-test. 
mRNA includes that encoded by SMN2 [14]; we have previously reported that p38 MAPK increases SMN protein expression by virtue of the binding of HUR protein to SMN2 3'UTR [6]. The VPAC2 receptor agonist Ro 25-1553 has been previously shown to activate the p38 MAPK pathway [9]; we wished to confirm that BAY 55-9837 could elicit the same p38 activation and that this was underlying the observed SMN protein induction. NT2 cells were therefore treated with BAY 55-9837 and then harvested; western blot analysis at the indicated time intervals revealed within one hour an increase in the ratio of phosphorylated/ total p38 protein (up to $24 \mathrm{hrs}$ after BAY 55-9837 treatment) consistent with p38 activation (Figure 2a-b). p38 MAPK activation was concurrent with the increase in SMN protein levels in NT2 cells (Figure 2a \& c). To confirm the role of p38 in the observed SMN protein induction, NT2 cells were pre-treated with the p38 inhibiting agent SB-239063 [17] for $2 \mathrm{~h}$ prior to treatment with BAY 55-9837 for $24 \mathrm{~h}$. Western blot analysis revealed that p38 inhibition effectively blocked the BAY 55-9837-mediated increase in SMN protein (Figure $2 \mathrm{~d} \& \mathrm{e}$ ). These results demonstrate that activation of p38 pathway presumable through binding of VPAC2 receptor agonist to its receptor confers the increase in SMN protein levels observed upon BAY 55-9837 treatment. This result is consistent with our previous observation of increased SMN protein levels conferred by the p38 MAPK activating small compounds anisomycin and celecoxib [6,7].

\section{BAY 55-9837 treatment upregulates SMN protein levels in vivo}

In order confirm that BAY 55-9837-mediated SMN protein induction extends to the in vivo setting, a dose finding study was initiated. CD-1 mice were given daily intraperitoneal (IP) BAY 55-9837 injections for 5 days 0.02, 0.2 and $2 \mathrm{mg} / \mathrm{kg}$ and brain and spinal cord samples then isolated for western blot analysis. Increased SMN protein levels were observed both in brain (Additional file 1: Figure S1a $\&$ b) and spinal cord samples (Additional file 1: Figure S1c \& d) following BAY 55-9837 treatment with the greatest induction ( 2 fold), seen at $0.2 \mathrm{mg} / \mathrm{kg}$ dose in CD-1 mice.

We next explored the impact of BAY 55-9837-induced SMN upregulation in a severe mouse model of the disease (SMA $\Delta 7$ mouse; $m S m n-/-; h S M N 2+/+, h S M N \Delta 7+/+$ [18]). SMA $\Delta 7$ mice were given $0.2 \mathrm{mg} / \mathrm{kg}$ BAY 55-9837 a
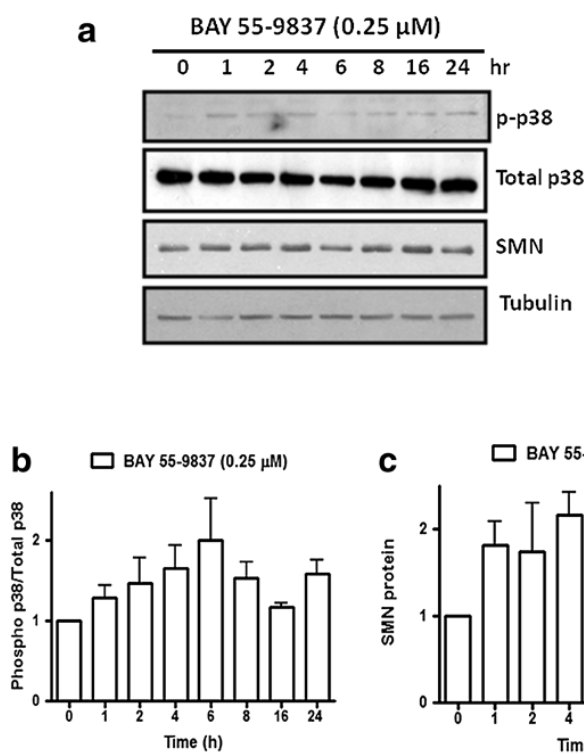

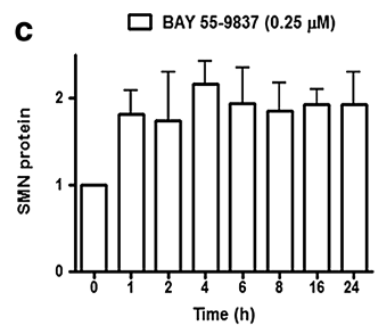

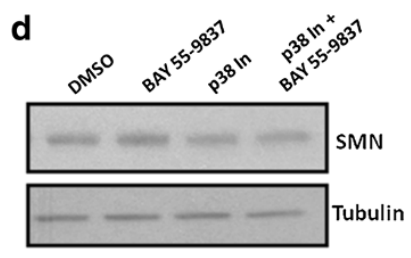

e

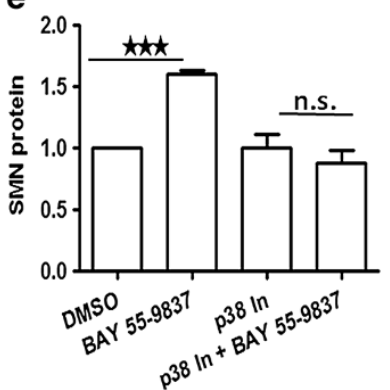

Figure 2 BAY 55-9837 treatment increases SMN expression via p38 MAPK pathway. (a) Representative western blot showing activation of p38 MAPK pathway upon BAY 55-9837 treatment in NT2 cells. NT2 cells were treated with BAY 55-9837 at indicated times and then harvested for western blot analysis. Activation of p38 pathway by BAY 55-9837 leads to an increase in SMN protein. (b) Densitometric quantification of phospho-p38 relative to total-p38 (the ratio at control treatment was set as 1; mean + SEM (bars) of three independent experiments) are shown for NT2 cells. (c) Densitometric quantification of SMN protein relative to Tubulin (the ratio at control treatment was set as 1; mean + SEM (bars) of three independent experiments) are shown for NT2 cells. (d) Representative western blots showing the effect of p38 inhibition on BAY 55-9837-induced increase in SMN protein. p38 inhibitor (SB-239580) blocked the BAY 55-9837-induced increase in SMN protein in NT2 cells. NT2 cells were treated with SB-239580 (p38 In; 3 MM) for $2 \mathrm{~h}$ followed by treatment with BAY 55-9837 for $24 \mathrm{~h}$ and than harvested for western blot analysis. (e) Densitometric quantification of SMN protein relative to Tubulin (the ratio at control treatment was set as 1; mean + SEM (bars) of three independent experiments) are shown for NT2 cells showing the effect of p38 inhibition on BAY 55-9837-induced increase in SMN protein. ${ }^{*} \mathrm{P}<0.05 ; *$ * $\mathrm{P}<0.01$, t-test. 
IP injections twice daily from P1 until P6. Mice were euthanized 24 hours after their last treatment and brain, spinal cord, muscle and heart samples then harvested for western blot analysis. Mice treated with BAY 55-9837 demonstrated an approximate doubling in SMN2-derived full length SMN protein levels in all tissues except brain where an approximate quadrupling of SMN protein was observed when compared with vehicle treated animals

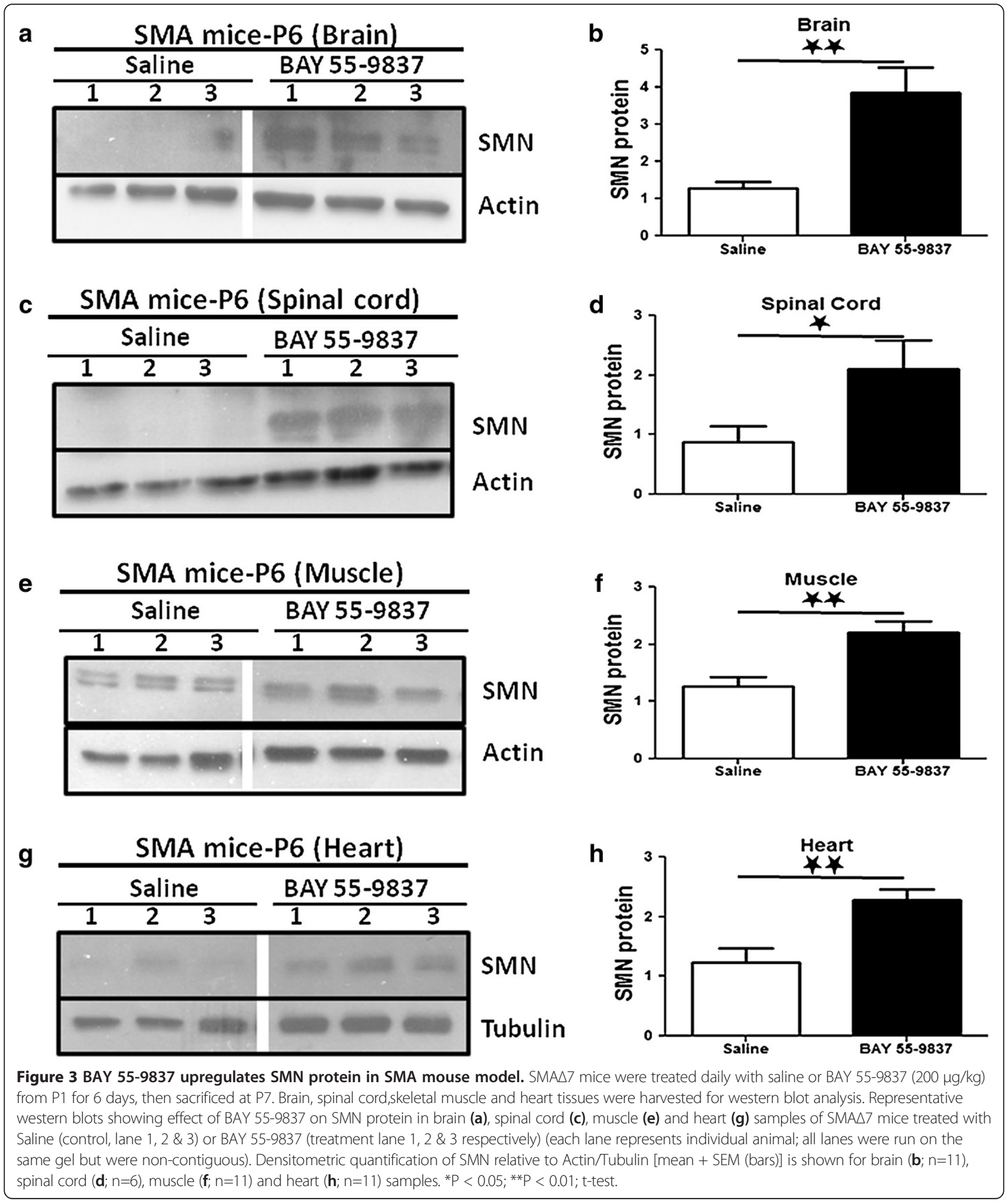


(Figure 3). In keeping with these results, VPAC2 receptors are expressed in CNS as well as in peripheral tissues [19-25]. The most modest (although still significant) induction of SMN protein was seen in muscle tissues compared to saline treated SMA mice, a possible result of the comparatively low amount of p38 transcript in SMA I muscle compared with normal muscle [26].

\section{BAY 55-9837 treatment improves disease phenotype in SMA mice model}

We next examined the effect of BAY 55-9837 treatment on SMA $\Delta 7$ mouse disease phenotype. The SMA $\Delta 7$ mice are significantly underweight and have reduced motor activity compared to heterozygous and WT littermates. SMA $\Delta 7$ mice were given twice daily BAY 55-9837 or vehicle IP injections starting at P1; their weight and motor function were assessed daily. SMA $\Delta 7$ mice treated with BAY 55-9837 showed significant improvement in weight gain and motor function (as assessed by righting time), as compared to vehicle-treated SMA $\Delta 7$ mice (Figure $4 \mathrm{a} \& \mathrm{~b}$ ).

We also examined the impact of BAY 55-9837 on survival in two different severe SMA mouse models (SMA $\Delta 7$ [18] and Taiw/Jax-SMA\{Cross between Taiwanese mice

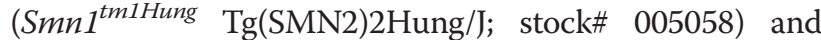
heterozygous Smn knock-out mice $\left(\mathrm{Smn}^{+/-}\right)$[11]\}. Significant extension of survival was observed in both mouse models upon treatment with BAY 55-9837 (median survival of $19.5 \mathrm{~d}$ for SMA $\Delta 7$ mice from $14 \mathrm{~d}$ and 12 days from 8d for Taiw/Jax SMA mice) as compared with vehicletreated (Figure 4c \& d). To account for the treatment effect variability between various laboratories and mouse models, the ratio of median survival of treated to non treated animals was used to assess drug response on survival. With BAY 55-9837 we have achieved a ratio of 1.39 (19.5d/14d for SMA $\Delta 7)$ \& 1.5 (12d/8d for Taiw/Jax-SMA) for the two different models. These numbers compare favourably with the other small compounds previously used for SMA treatment such as TSA $(1.2 ; 19 \mathrm{~d} / 16 \mathrm{~d}$ albeit P5 TSA initiation in SMA $\Delta 7)$ [10], SAHA $(1.3 ; 12.9 \mathrm{~d} / 9.9 \mathrm{~d}$ in Taiw/Jax-SMA) [11], celecoxib $(1.38 ; 18 \mathrm{~d} / 13 \mathrm{~d})$ [7] and Prolactin $(1.5 ; 21 d / 14 d)$ [27].

SMA is primarily considered as a motor neuron disease and consequently treatment strategies focus on drugs which can cross the blood brain barrier (BBB) to target tissues within central nervous system (CNS). However several recent studies challenge this notion and suggest that SMN has function above and beyond motor
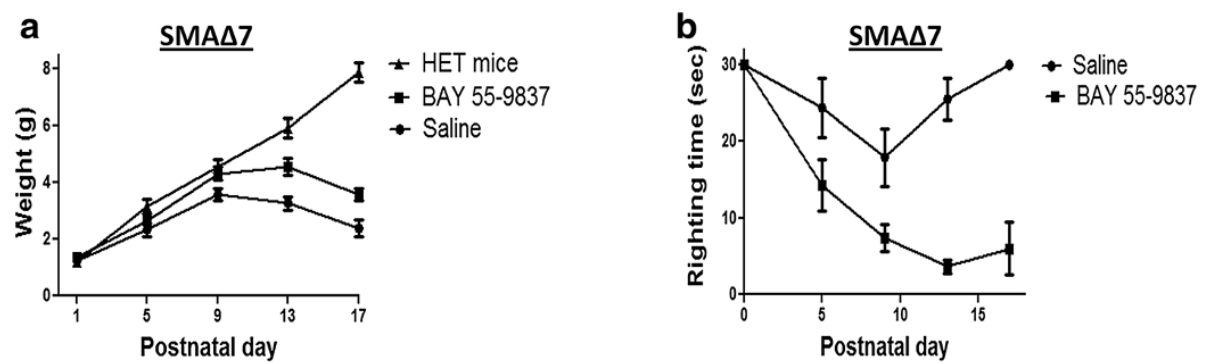

\section{Survival data}
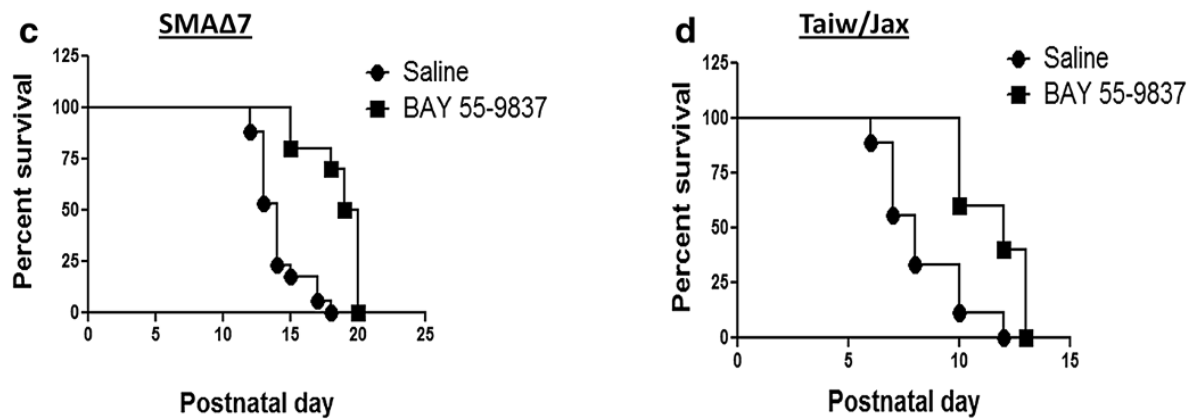

Figure 4 BAY 55-9837 ameliorates disease phenotype and increases survival of SMA mouse models. SMA $\triangle 7$ mice were treated daily with intraperitoneal injections of BAY 55-9837 (200.0 $\mu \mathrm{g} / \mathrm{kg}$ ) from P1 onward. (a) Weights of SMA $\triangle 7$ mice treated with BAY 55-9837 (black filled square, $n=10$ ) or saline (black filled circle, $n=10$ ); weights for heterozygous mice treated with saline (black filled triangle, $n=5$ ) are also shown for comparison [mean \pm SEM (bars)]. (b) Righting times of SMA $\triangle 7$ mice treated with BAY 55-9837 (black filled square, $n=10)$ or saline (black filled circle, $n=10$ ) [mean \pm SEM (bars)]. (c) Kaplan-Meier survival curves of SMA $\triangle 7$ mice treated with BAY 55-9837 (black filled square, $n=10$; median survival 19.5 days) or saline (black filled circle, $n=17$; median survival 14.0 days ). (d) Kaplan-Meier survival curves of Taiwanese-SMA mice treated with BAY 55-9837 (black filled square, $n=5$; median survival 12.0 days) or saline (black filled circle, $n=10$; median survival 8.0 days); ${ }^{*} \mathrm{P}<0.05$; ***P $<0.0001$, log-rank test. 


\section{Model for VPAC-2 receptor agonist (BAY 55-9837) action}

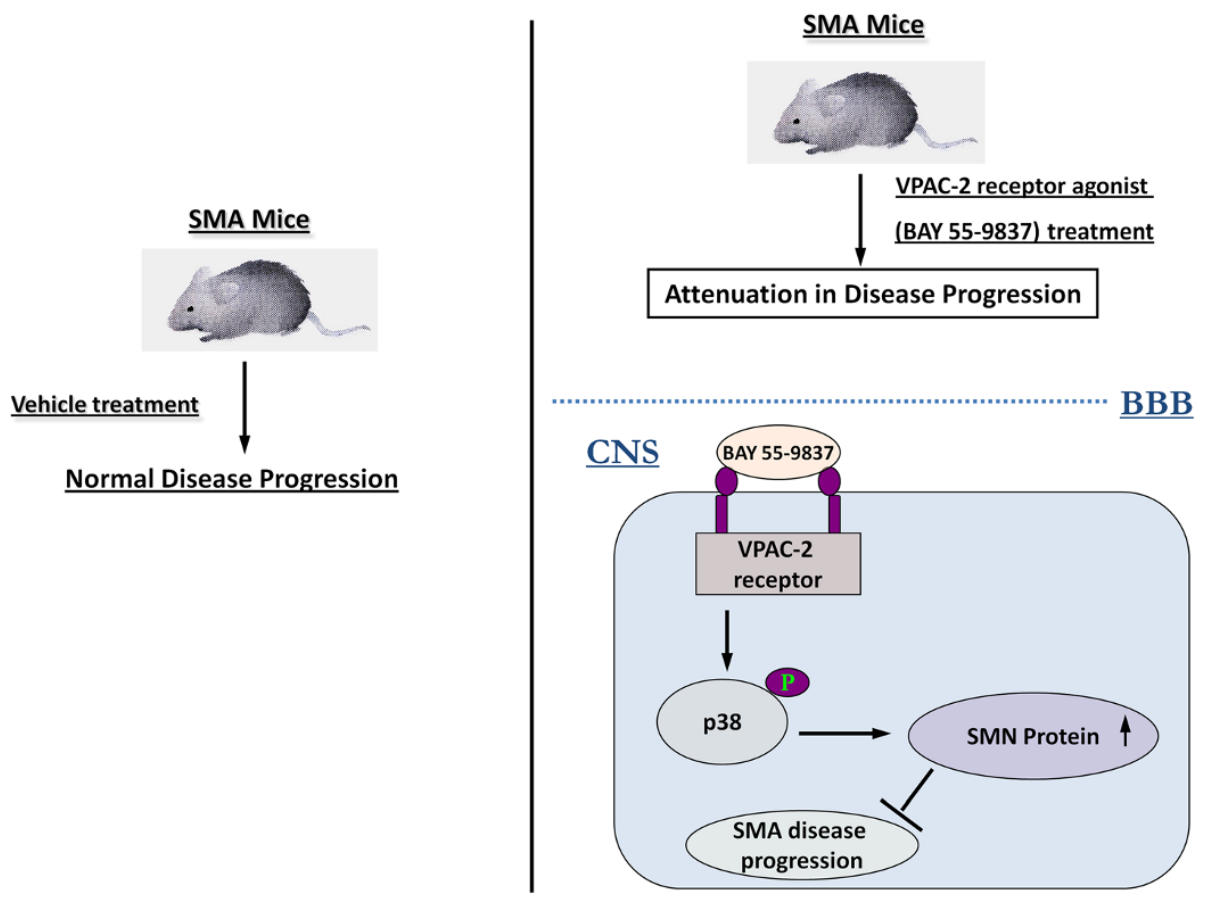

Figure 5 Model for VPAC2 receptor agonist (BAY 55-9837) action.

neurons and reclassify SMA as a multi-system disorder (including cardiovascular, peripheral necrosis, pancreatic and liver defects) [28-36]. In this regard the widespread presence of the VPAC2 receptor augurs well for this pathway as a therapeutic SMA target [25].

\section{Conclusion}

Re-purposing drugs for distinct disease indications is becoming a more common practice given the approximately 7000 orphan genetic disorders that are estimated to exist. This approach is both cost-effective as well as shortening the path to treatment for significant (and currently untreatable) disorders such as SMA. In the current study, BAY 55-9837 initially developed for the treatment of diabetes $[37,38]$ has been used as a p38 activating compound for the treatment of murine SMA. Our results demonstrate that VPAC2 receptor agonist BAY 55-9837 increases SMN protein levels and attenuates disease progression in two distinct severe SMA mouse models (Figure 5) providing a proof of concept and support for other VPAC2 agonists/p38 activating compounds to be tested as effective SMA therapies. Although the literature on the safety profile of BAY 55-9837 is divided (e.g. 38 and 39), in our experiments we did not observe any adverse effects. Nevertheless further work to obtain comprehensive safety profile for BAY 55-9837 will be beneficial [39]. This study provides a good supportive evidence as well as functional insight how $\mathrm{p} 38$ pathway can be targeted for its potential application towards development of therapeutics for SMA.

\section{Additional file}

Additional file 1: Figure S1. BAY 55-9837 upregulates Smn protein in wild type mice. 4 weeks old CD-1 wild type mice were treated daily with BAY 55-9837 $(2.0,20.0,200.0 \mu \mathrm{g} / \mathrm{kg})$ for 5 days, then sacrificed. Brain and spinal cord tissues were harvested for western blot analysis. (a) Representative western blot showing the effect of BAY 55-9837 on Smn protein in brain samples of CD-1 mice treated with saline (control, lane-1) or BAY 55-9837 (lane 2, 3 \& 4 respectively) $(n=3)$. (b) Densitometric quantification of SMN relative to Tubulin [mean + SEM (bars)] is shown for brain samples. (c) Representative western blot showing the effect of BAY 559837 on SMN protein in spinal cord samples of CD-1 mice treated with Saline (control, lane-1) or BAY 55-9837 (lane 2, 3 \& 4) $(n=3)$. (d) Densitometric quantification of SMN relative to Tubulin [mean + SEM (bars)] is shown for spinal cord samples. ${ }^{*} \mathrm{P}<0.05$, t- test.

\section{Competing interests}

The authors declare that they have no competing interests.

\section{Authors' contributions}

FF designed and executed the experiments, analyzed the data, and wrote the manuscript; $\mathrm{JH}$, and DM assisted with the experiments and analysis of the data; FS and KM assisted with the experiments; MH and AM assisted with analysis and writing. All authors read and approved the final manuscript.

\section{Acknowledgments}

We want to thank Nathalie Earl for technical help with mice treatment. We would also like to thank Animal Care and Veterinary Service staff at the University of Ottawa.. This work was supported by operating grants from the Canadian Gene Cure Foundation and CIHR Institute of Genetics (to F. Farooq), and from Tori's Buddies, CML Healthcare, FightSMA, the SMA Foundation, the 
Canadian Gene Cure Foundation, Physicians Services Incorporated, Ilsa Mae SMA Research Fund and the Canadian Institutes of Health Research (to A. MacKenzie)

Received: 13 November 2013 Accepted: 3 January 2014

Published: 9 January 2014

\section{References}

1. Sugarman EA, Nagan N, Zhu H, Akmaev VR, Zhou Z, Rohlfs EM, Flynn K, Hendrickson BC, Scholl T, Sirko-Osadsa DA, Allitto BA: Pan-ethnic carrier screening and prenatal diagnosis for spinal muscular atrophy: clinical laboratory analysis of $>72,400$ specimens. Eur J Hum Gen 2012, 20:27-32.

2. D'Amico A, Mercuri E, Tiziano FD, Bertini E: Spinal muscular atrophy. Orphanet J Rare Dis 2011, 6:71.

3. Lefebvre $S$, Burglen $L$, Reboullet $S$, Clermont $O$, Burlet $P$, Viollet $L$, Benichou B, Cruaud C, Millasseau P, Zeviani M: Identification and characterization of a spinal muscular atrophy-determining gene. Cell 1995, 80:155-165.

4. Lorson CL, Hahnen E, Androphy EJ, Wirth B: A single nucleotide in the SMN gene regulates splicing and is responsible for spinal muscular atrophy. Proc Natl Acad Sci USA 1999, 96:6307-6311.

5. Monani UR, Lorson CL, Parsons DW, Prior TW, Androphy EJ, Burghes AH, McPherson JD: A single nucleotide difference that alters splicing patterns distinguishes the SMA gene SMN1 from the copy gene SMN2. Hum Mol Genet 1999, 8:1177-1183.

6. Faroog F, Balabanian S, Liu X, Holcik M, MacKenzie A: p38 Mitogen-activated protein kinase stabilizes SMN mRNA through RNA binding protein HuR. Hum Mol Genet 2009, 18:4035-4045.

7. Farooq F, Abadia-Molina F, MacKenzie D, Hadwen J, Shamim F, O'Reilly S, Holcik M, MacKenzie A: Celecoxib increases SMN and survival in a severe spinal muscular atrophy mouse model via p38 pathway activation. Hum Mol Genet 2013, 22:3415-3424.

8. Garry EM, Delaney A, Blackburn-Munro G, Dickinson T, Moss A, Nakalembe I, Robertson DC, Rosie R, Robberecht P, Mitchell R, Fleetwood-Walker SM: Activation of p38 and p42/44 MAP kinase in neuropathic pain: involvement of VPAC2 and NK2 receptors and mediation by spinal glia. Mol Cell Neurosci 2005, 30:523-537.

9. Monaghan TK, Mackenzie CJ, Plevin R, Lutz EM: PACAP-38 induces neuronal differentiation of human SH-SY5Y neuroblastoma cells via CAMP-mediated activation of ERK and p38 MAP kinases. J Neurochem 2008, 104:74-88.

10. Avila AM, Burnett BG, Taye AA, Gabanella F, Knight MA, Hartenstein P, Cizman Z, Di Prospero NA, Pellizzoni L, Fischbeck KH, Sumner CJ: Trichostatin A increases SMN expression and survival in a mouse model of spinal muscular atrophy. J Clin Invest 2007, 117:659-671.

11. Riessland M, Ackermann B, Forster A, Jakubik M, Hauke J, Garbes L, Fritzsche I, Mende Y, Blumcke I, Hahnen E, Wirth B: SAHA ameliorates the SMA phenotype in two mouse models for spinal muscular atrophy. Hum Mol Genet 2010, 19:1492-1506.

12. Brook M, Sully G, Clark AR, Saklatvala J: Regulation of tumour necrosis factor alpha mRNA stability by the mitogen-activated protein kinase p38 signalling cascade. FEBS Lett 2000, 483:57-61.

13. Dean JL, Brook M, Clark AR, Saklatvala J: p38 mitogen-activated protein kinase regulates cyclooxygenase- 2 mRNA stability and transcription in lipopolysaccharide-treated human monocytes. J Biol Chem 1999, 274:264-269.

14. Frevel MA, Bakheet T, Silva AM, Hissong JG, Khabar KS, Williams BR: p38 Mitogen-activated protein kinase-dependent and -independent signaling of mRNA stability of AU-rich element-containing transcripts. Mol Cell Biol 2003, 23:425-436.

15. Rutault K, Hazzalin CA, Mahadevan LC: Combinations of ERK and p38 MAPK inhibitors ablate tumor necrosis factor-alpha (TNF-alpha ) mRNA induction. Evidence for selective destabilization of TNF-alpha transcripts. J Biol Chem 2001, 276:6666-6674.

16. Wang SW, Pawlowski J, Wathen ST, Kinney SD, Lichenstein HS, Manthey CL: Cytokine mRNA decay is accelerated by an inhibitor of p38-mitogenactivated protein kinase. Inflamm Res 1999, 48:533-538.

17. Legos JJ, Erhardt JA, White RF, Lenhard SC, Chandra S, Parsons AA, Tuma RF, Barone FC: SB 239063, a novel p38 inhibitor, attenuates early neuronal injury following ischemia. Brain Res 2001, 892:70-77.
18. Le TT, Pham LT, Butchbach ME, Zhang HL, Monani UR, Coovert DD, Gavrilina TO, Xing L, Bassell GJ, Burghes AH: SMNDelta7, the major product of the centromeric survival motor neuron (SMN2) gene, extends survival in mice with spinal muscular atrophy and associates with full-length SMN. Hum Mol Genet 2005, 14:845-857.

19. Basille M, Cartier D, Vaudry D, Lihrmann I, Fournier A, Freger $P$, Gallo-Payet N, Vaudry H, Gonzalez B: Localization and characterization of pituitary adenylate cyclase-activating polypeptide receptors in the human cerebellum during development. J Comp Neurol 2006 496:468-478

20. Harmar AJ, Sheward WJ, Morrison CF, Waser B, Gugger M, Reubi JC: Distribution of the VPAC2 receptor in peripheral tissues of the mouse. Endocrinology 2004, 145:1203-1210.

21. Kalamatianos T, Kallo I, Piggins HD, Coen CW: Expression of VIP and/or PACAP receptor $\mathrm{mRNA}$ in peptide synthesizing cells within the suprachiasmatic nucleus of the rat and in its efferent target sites. J Comp Neurol 2004, 475:19-35.

22. Reubi JC: In vitro evaluation of VIP/PACAP receptors in healthy and diseased human tissues. Clinical implications. Ann N Y Acad Sci 2000 921:1-25.

23. Reubi JC, Laderach U, Waser B, Gebbers JO, Robberecht P, Laissue JA: Vasoactive intestinal peptide/pituitary adenylate cyclase-activating peptide receptor subtypes in human tumors and their tissues of origin. Cancer Res 2000, 60:3105-3112.

24. Schulz S, Rocken C, Mawrin C, Weise W, Hollt V, Schulz S: Immunocytochemical identification of VPAC1, VPAC2, and PAC1 receptors in normal and neoplastic human tissues with subtype-specific antibodies. Clin Cancer Res 2004, 10:8235-8242.

25. Sherwood NM, Krueckl SL, McRory JE: The origin and function of the pituitary adenylate cyclase-activating polypeptide (PACAP)/glucagon superfamily. Endocr Rev 2000, 21:619-670

26. Millino C, Fanin M, Vettori A, Laveder P, Mostacciuolo ML, Angelini C, Lanfranchi G: Different atrophy-hypertrophy transcription pathways in muscles affected by severe and mild spinal muscular atrophy. BMC Med 2009, 7:14

27. Faroog F, Molina FA, Hadwen J, MacKenzie D, Witherspoon L, Osmond M, Holcik M, MacKenzie A: Prolactin increases SMN expression and survival in a mouse model of severe spinal muscular atrophy via the STAT5 pathway. J Clin Invest 2011, 121:3042-3050.

28. Araujo A, Araujo M, Swoboda KJ: Vascular perfusion abnormalities in infants with spinal muscular atrophy. J Pediatr 2009, 155:292-294.

29. Bevan AK, Hutchinson KR, Foust KD, Braun L, McGovern VL, Schmelzer L, Ward JG, Petruska JC, Lucchesi PA, Burghes AH, Kaspar BK: Early heart failure in the SMNDelta7 model of spinal muscular atrophy and correction by postnatal scAAV9-SMN delivery. Hum Mol Genet 2010, 19:3895-3905

30. Bowerman M, Swoboda KJ, Michalski JP, Wang GS, Reeks C, Beauvais A, Murphy K, Woulfe J, Screaton RA, Scott FW, Kothary R: Glucose metabolism and pancreatic defects in spinal muscular atrophy. Ann Neurol 2012, 72:256-268

31. Gogliotti RG, Quinlan KA, Barlow CB, Heier CR, Heckman CJ, Didonato CJ: Motor neuron rescue in spinal muscular atrophy mice demonstrates that sensory-motor defects are a consequence, not a cause, of motor neuron dysfunction. J Neurosci 2012, 32:3818-3829.

32. Heier CR, Satta R, Lutz C, DiDonato CJ: Arrhythmia and cardiac defects are a feature of spinal muscular atrophy model mice. Hum Mol Genet 2010, 19:3906-3918

33. Hua Y, Sahashi K, Rigo F, Hung G, Horev G, Bennett CF, Krainer AR: Peripheral SMN restoration is essential for long-term rescue of a severe spinal muscular atrophy mouse model. Nature 2011, 478:123-126.

34. Martinez TL, Kong L, Wang X, Osborne MA, Crowder ME, Van Meerbeke JP, Xu X, Davis C, Wooley J, Goldhamer DJ, et al: Survival motor neuron protein in motor neurons determines synaptic integrity in spinal muscular atrophy. J Neurosci 2012, 32:8703-8715.

35. Rudnik-Schoneborn S, Vogelgesang S, Armbrust S, Graul-Neumann L, Fusch $C$, Zerres K: Digital necroses and vascular thrombosis in severe spinal muscular atrophy. Muscle Nerve 2010, 42:144-147.

36. Shababi M, Habibi J, Yang HT, Vale SM, Sewell WA, Lorson CL: Cardiac defects contribute to the pathology of spinal muscular atrophy models Hum Mol Genet 2010, 19:4059-4071. 
37. Pan CQ, Li F, Tom I, Wang W, Dumas M, Froland W, Yung SL, Li Y, Roczniak $\mathrm{S}$, Claus TH, et al: Engineering novel VPAC2-selective agonists with improved stability and glucose-lowering activity in vivo. $J$ Pharmacol Exp Ther 2007, 320:900-906.

38. Tsutsumi M, Claus TH, Liang Y, Li Y, Yang L, Zhu J, Dela Cruz F, Peng X, Chen H, Yung SL, et al: A potent and highly selective VPAC2 agonist enhances glucose-induced insulin release and glucose disposal: a potential therapy for type 2 diabetes. Diabetes 2002, 51:1453-1460.

39. Darsalia V, Mansouri S, Wolbert P, Barde S, Sjoholm A, Patrone C: The specific VPAC2 agonist Bay 55-9837 increases neuronal damage and hemorrhagic transformation after stroke in type 2 diabetic rats. Neuropeptides 2012, 47:133-137.

doi:10.1186/1750-1172-9-4

Cite this article as: Hadwen et al:: VPAC2 receptor agonist BAY 55-9837 increases SMN protein levels and moderates disease phenotype in severe spinal muscular atrophy mouse models. Orphanet Journal of Rare Diseases 2014 9:4.

\section{Submit your next manuscript to BioMed Central and take full advantage of:}

- Convenient online submission

- Thorough peer review

- No space constraints or color figure charges

- Immediate publication on acceptance

- Inclusion in PubMed, CAS, Scopus and Google Scholar

- Research which is freely available for redistribution 